\author{
Matti Salo MD PhD, * \\ Mika J. Mäkelä MD MSc PhD, ${ }^{\dagger}$ \\ Juha Perttilä MD PhD, * \\ Jorma Ilonen MD PhD
}

\section{Enhanced spontaneous antibody response after coronary artery bypass surgery}

Purpose: Cells spontaneously secreting immunoglobulins can be seen in the blood one week after open-heart surgery. The purpose of this study was to measure the antibody specificities of activated cells.

Methods: Immune responses were studied preoperatively and on the seventh postoperative day in 18 patients undergoing elective coronary artery bypass surgery. The number of cells secreting adenovinus, measles, rubella and tetanus antigen specific antibodies spontaneously and induced by pokeweed mitogen PWM (ASCs) as well as the total number of cells secreting IgG. IgM and IgA (ISCs) were studied using an enzyme-linked immunospot (ELISPOT) assay. Spontaneous as well as phytohaemagglutinin (PHA)- and pokeweed mitogen (PWM)-induced lymphocyte proliferation was also measured.

Results: The number of cells spontaneously secreting lgG, IgM and lgA antibodies was increased on the se venth day after coronary bypass surgery, against adenovinus, measles, nubella and tetanus as well as the total number of cells secreting immunoglobulins $\lg$, IgM and $\lg A(P<0.05 / 0.001)$. By contrast, only slight fluctuation was seen in the numbers of cells secreting antibodies after PWM stimulation. Spontaneous lymphocyte proliferation was also increased. PHA proliferative responses were depressed and PWM responses were not changed on the seventh postoperative day compared with preoperative values.

Conclusion: Coronary artery bypass surgery caused marked polyclonal B cell activation demonstrated by an increase of cells producing spontaneously antibodies against virus antigens and tetanus toxoid. This activation could not be intensified by PWM stimulation.

Objectif : Une semaine après une chirurgie à coeur ouvert, on retrouve dans le sang des cellules qui sécrètent des immunoglobulines. Cette étude visait à mesurer la spécificité des anticorps propres aux cellules activées.

Méthodes : Les réponses immunitaires de 18 patients ont été étudiées avant une chirurgie de revascularisation myocardique non urgente et sept jours plus tard. Le nombre de cellules sécrétant spontanément des anticorps spécifiques aux adénovirus. à la rougeole. à la rubéole et au tétanos et les anticorps induits par le mitogème pokeweed PWM (ASC) ainsi que le nombre total des cellules sécrétant des lgG. IgM et lgA (ISC) ont été étudiées avec une épreuve d'immunospot lié aux enzymes (ELISPOT). En plus de la prolifération spontanée, la prolifération lymphocytaire induite par la phytohémagglutinine (PHA) et par le mitogène pokeweed a été mesurée.

Résultats : Le septième jour après lintervention, on constatait une augmentation du nombre de cellules sécrétant spontanément des anticorps lgG. IgM et lgA contre les adénovirus, la rougeole, la rubéole et le tétanos aussi bien que du nombre de cellules sécrétant des immunoglobulines $\lg G$, lgM et $\lg A(P<0.05 / 0,001)$. Par contre, seulement de légères fluctuations ont été notées dans le nombre de cellules sécrétant des anticorps après la stimulation par le PWM. La prolifération lymphocytaire spontanée augmentait aussi, les réponses PHA prolifératrices étaient déprimées et les réponses PWM ne changeaient pas la septième journée postoperatoire comparativement aux valeurs préopératoires.

Conclusion : La chirurgie de revascularisation myocardique provoque une importante activation polyclonale des cellules $B$ qui se manifeste par une augmentation des cellules produisant spontanément des anticorps contre les antigènes viraux et la toxoïde tétanique. Cette activation n'est pas intensifiée par la stimulation par le PWM.

From Turku Immunology Centre and Departments of Anaesthesiology, ${ }^{*}$ Virology, ${ }^{\ddagger}$ Paediatrics, ${ }^{\dagger}$ Pulmonary Diseases and Clinical Allergology ${ }^{\dagger}$ University of Turku, FIN-20520 Turku, Finland. Supported by grants from the Turku University Foundation and the Paulo Foundation. Presented, in part at the 11 th World Congress of Anaesthesiologists in Sydrey, Australia, 1996.

Address correspondence to: Dr Matti Salo, Department of Anaesthesiology, University of Turku, FIN-20520 Turku, Finland,

Phone: +358 - 2-2611969; Fax +358 - 2 - 2613960; E-mail: Matti.Salo@ityks.fi Accepted for publication, 15 Marcb 1997. 
I

MMUNOLOGICAL homeostasis is affected by anaesthesia and surgery. The specific immune response shows lymphopaenia, depressed cellmediated immunity and alterations in $B$ cell responses. ${ }^{1}$ Spontaneous proliferation of lymphocytes increases over the first seven days after open-heart surgery ${ }^{2,3}$ and other types of surgery. ${ }^{4}$ Increased numbers of cells spontaneously secreting IgG, IgM and IgA have been simultaneously observed on the seventh postoperative day in the peripheral circulation. ${ }^{3}$ This study was carried out to characterize this activation by measuring the antibody specificities of these surgeryactivated cells. The number of cells secreting specific IgG, IgM and IgA antibodies spontaneously and after pokeweed mitogen (PWM) induction was calculated. A panel of ubiquitous antigens was chosen which contained measles, rubella and adenovirus, and tetanus toxoid against which an extensive immunization program in the Finnish population has been conducted.

\section{Methods}

\section{Patients}

The study was conducted according to the principles on human experimentation of the Helsinki Declaration and approved by the Ethical Committee of the Turku University Medical Faculty and the Turku University Central Hospital. Informed consent was obtained from each patient. Eighteen male patients (mean age $60 \pm 10$ (SD) yr, weight $88 \pm 12 \mathrm{~kg}$, height $178 \pm 8 \mathrm{~cm}$ and ASA class 4) undergoing elective coronary artery bypass surgery were studied. Concomitant medication including long-acting nitrates, calcium channel blockers and $\mathrm{B}$ adrenergic receptor blockers was continued until the morning of surgery. Patients with a history of malignant, haematological or endocrinological disease or who were receiving immunosuppressive drugs were excluded.

The operations were carried out under moderatedose fentanyl anaesthesia supplemented with lorazepam, isoflurane and pancuronium. The patients received $6 \mu \mathrm{g} \cdot \mathrm{kg}^{-1}$ scopolamine and $0.2 \mathrm{mg} \cdot \mathrm{kg}^{-1}$ morphine sc as preanaesthetic medication $60-90 \mathrm{~min}$ before operation and at induction of anaesthesia $4 \mathrm{mg}$ lorazepam and $30 \mu \mathrm{g} \cdot \mathrm{kg}^{-1}$ fentanyl, followed by an infusion of $0.1-0.2 \mu \mathrm{g} \cdot \mathrm{kg}^{-1} \cdot \mathrm{hr}^{-1}$ fentanyl. The inspiratory concentration of isoflurane was $0.2-1.5 \mathrm{v} / \mathrm{v} \%$. Mechanical ventilation was used with oxygen $40 \%$ in air. Moderate $\left(30^{\circ} \mathrm{C}\right)$ systemic hypothermia was used during extracorporeal circulation. The roller-pump heart-lung-machine with a hollow fibre oxygenator (Dideco D 703 Compactflo System; Dideco S.p.A., Mirandola, Italy), cardiotomy reservoir/venous reservoir and customized polyvinyl chloride tubing including an arterial line leucocyte nondepleting filter (Micro
20A, Dideco) was primed with $2000 \mathrm{ml}$ of a crystalloid solution and $100 \mathrm{ml}$ of mannitol $15 \%$. The flow rate was $2.4 \mathrm{l} \cdot \mathrm{min}^{-1} \cdot \mathrm{m}^{-2}$ body surface area, reduced to 1.9 $1 \cdot \mathrm{min}^{-1} \cdot \mathrm{m}^{-2}$ during hypothermia. Anticoagulation was maintained using porcine heparin (initial dose 3 $\left.\mathrm{mg} \cdot \mathrm{kg}^{-1}\right)$. Activated clotting time was maintained over $400 \mathrm{sec}$ throughout the extracorporeal circulation. Cardioplegic arrest was achieved with cold $\left(4^{\circ} \mathrm{C}\right)$ St. Thomas's solution $(1000 \mathrm{ml})$ and local cooling with ice-slush in the pericardial cradle. Invasive central haemodynamics were monitored during and after operation using a pulmonary artery catheter and a radial artery cannula. In addition, the ECG, oxygen saturation and end-tidal $\mathrm{CO}_{2}$ concentrations were monitored. No remarkable haemodynamic instability occurred in any of the patients. No corticosteroids were used. The median number of grafts was three (range 2-5), and the mean duration of anaesthesia, surgery and extracorporeal perfusion was $234 \pm 31$ (SD) $\mathrm{min}, 176 \pm 30 \mathrm{~min}$ and $99 \pm 28 \mathrm{~min}$, respectively. Autologous blood transfusion was used, and all except one patient also received Sagman packed red blood cells, median two units (range one - nine). After operation, the lungs were ventilated in normocapnia until the first postoperative morning and then the tracheas were extubated. The patients received $1.5 \mathrm{~g}$ cefuroxime iv before operation and $750 \mathrm{mg}$ three times daily for three postoperative days. No operative or other complications or infections occurred.

In addition, five healthy volunteers from the hospital staff (mean age $40 \pm 9$ (SD) yr, weight $78 \pm 14 \mathrm{~kg}$ and height $179 \pm 8 \mathrm{~cm}$ ) were used as a control group to test the stability of the methods. The control group volunteers did not differ in their background data from the patients (Student's t test).

\section{Blood samples}

Processing of the heparinized venous blood samples, taken on the morning before operation and on the morning of the seventh postoperative day, was started immediately after collection. Haemoglobin concentrations, haematocrit as well as leucocyte and differential counts were determined using the $\mathrm{H} 6000$ blood cell analyzer (Technicon Instruments Co., Tarrytown, NY, USA). Mononuclear cells were separated in FicollIsopaque (Ficoll-Paque, ${ }^{\circledR}$ Pharmacia Fine Chemicals, Uppsala, Sweden) by centrifugation at $400 \mathrm{~g}$ for $40 \mathrm{~min}$ at $+4^{\circ} \mathrm{C}$ and then washed twice with Hanks' balanced salt solution and diluted in RPMI 1640 medium (Gibco, Grand Island, NY, USA). ${ }^{5}$ The purity of the mononuclear cell yield was evaluated, and viability of cells over 95\% was determined by the trypan blue exclusion method. 


\section{Measurement of antibody secreting cells}

The number of cells showing spontaneous and PWMinducible specific antibody secretion cells (ASCs) and the number of immunoglobulin secreting cells (ISCs) in blood samples were measured using an enzymelinked solid-phase immunospot (ELISPOT) assay. ${ }^{6}$ The method has been described recently in the measurement of virus-specific ASCs. ${ }^{7}$

Briefly, for the calculation of specific ASC numbers, flat-bottomed 96-well microtitre plates (NuncImmuno Plate Maxisorp, ${ }^{\mathrm{TM}}$ Nunc $\mathrm{A} / \mathrm{S}$, Roskilde, Denmark) were precoated with $50 \mu$ of the antigens including adenovirus hexon $5 \mu \mathrm{g} \cdot \mathrm{ml}^{-1(8)}$, measles virus lysate $40 \mu \mathrm{g} \cdot \mathrm{ml}^{-1(9)}$, rubella semipurified virions 20 $\mu \mathrm{g} \cdot \mathrm{ml}^{-1(10)}$ or tetanus toxoid $5 \mu \mathrm{g} \cdot \mathrm{ml}^{-1}$ (National Public Health Institute, Helsinki, Finland). For the measurement of ISC numbers, the plates were coated with $50 \mu \mathrm{l}$ goat antihuman IgG (Zymed, San Fransisco, Ca, USA), IgM (Dako, Glostrup, Denmark) or IgA (Dako) by incubating them for two hours at $37^{\circ} \mathrm{C}$ ). After washing and blocking of nonspecific binding with bovine serum albumin (BSA)-PBS (phosphate-buffered saline), the plates were incubated with $50 \mu \mathrm{l}$ of three dilutions of isolated mononuclear cell suspension $\left(2 \times 10^{5}, 1 \times 10^{5}\right.$ or $0.5 \times 10^{5}$ cells.well $^{-1}$ for determination of antigen specific ASC numbers and $1 \times 10^{4}, 0.25 \times 10^{4}$ or $0.062 \times 10^{4}$ cells-well ${ }^{-1}$ for determination of ISC numbers in quad ruplicate). After two hours of incubation at $37^{\circ} \mathrm{C}$, the plates were washed three times with PBS-Tween, and $50 \mu \mathrm{l}$ alkaline phosphatase-conjugated antihuman IgG (Orion, Espoo, Finland for ASCs and Sigma, St Louis, MO, USA for ISCs), IgM or IgA (Orion) diluted 1:100 in PBS $+1 \%$ BSA was added for determination of specific ASC and ISC numbers. The plates were then incubated overnight at $4^{\circ} \mathrm{C}$. After another four washes with PBS-Tween, $50 \mu \mathrm{l}$ substrate-agarose were overlaid.

Substrate-agarose was prepared as follows: $0.6 \mathrm{~g}$ low-electroendosmosis agarose (Sigma) was boiled in $20 \mathrm{ml}$ distilled water until completely dissolved. Then, $5 \mathrm{ml}$ 5-bromo-4-chloro-3-indolylphosphate (Sigma) dissolved in 2-amino-2-methyl-I-propanol (Fluka, Buchs, Switzerland) was added to the above $20 \mathrm{ml}$ of agar 3\% solution, after which substrate-agarose was ready for use. The ASCs and ISCs were observed after overnight incubation in the dark at room temperature and visualized as dark blue spots under a stereomicroscope. The results are given as ASC or ISC numbers per $10^{6}$ isolated mononuclear cells.

For the assessment of antibody secreting cells after PWM stimulation $2 \times 10^{6}$ separated mononuclear cells were first cultured in $2 \mathrm{ml}$ test tubes with $10 \mu \mathrm{g} \cdot \mathrm{ml}^{-1}$ $\mathrm{PWM}$ in humidified air and $\mathrm{CO}_{2} 5 \%$ at $37^{\circ} \mathrm{C}$ for seven days. Then, the same assay as that for measurement of cells spontaneously secreting antibodies was used.

\section{Measurement of lymphocyte proliferative responses} Separated mononuclear cells $\left(1 \times 10^{5}\right)$ were cultured in quadruplicate in RPMI 1640 (Gibco) with 50 $\mu \mathrm{g} \cdot \mathrm{ml}^{-1}$ gentamicin, $\mathrm{AB}$ serum $10 \%$ and mitogens in wells of flat-bottomed microtitre plates in humidified air and $\mathrm{CO}_{2} 5 \%$ at $37^{\circ} \mathrm{C}$ for seven days. ${ }^{11}$ The culture mitogens were $100 \mu \mathrm{g} \cdot \mathrm{ml}^{-1}$ phytohemagglutinin (PHA, Difco Detroit, MI, USA) and $2.5 \mu \mathrm{g} \cdot \mathrm{ml}^{-1}$ pokeweed mitogen (PWM, Gibco). The volume of each culture was $200 \mu \mathrm{l}$. Eighteen hours before harvesting, $1 \mu \mathrm{Ci}$ of ${ }^{3} \mathrm{H}$-thymidine (specific activity 98 mCi-mg ${ }^{-1}$, Radiochemical Centre, Amersham, UK) in $20 \mu \mathrm{l}$ was added to each microculture. Radioactivity was measured as disintegrations per minute (dpm) of ${ }^{3} \mathrm{H}$-thymidine incorporation into DNA, using a scintillation counter (LKB-Wallac, Turku, Finland).

\section{Statistics}

The Wilcoxon matched paired test was used to compare pre- and postoperative values. Student's $t$ test and the Mann-Whitney U test were used to compare preoperative values between patients and volunteers who served as methodological controls.

\section{Results}

The number of leucocytes, percentage of neutrophils, eosinophils and basophils were increased and the percentage of lymphocytes decreased on the seventh postoperative day from preoperative values $(P<0.05-$ 0.001 ) (Table I). The absolute numbers of lymphocytes in the circulation were at the preoperative level on the

TABLE I Blood haemoglobin concentrations, haematocrit and blood cell counts in patients before operation (I) and on the seventh postoperative day (II). Means (SD), $n=18$.

\begin{tabular}{lrrrrr}
\hline & \multicolumn{4}{c}{$I$} & \multicolumn{3}{c}{$I I$} \\
\hline Haemoglobin, g $\cdot \mathrm{I}^{-1}$ & 141 & $(10.4)$ & 127 & $(11.3)$ & $* * *$ \\
Haematocrit & 0.41 & $(0.03)$ & 0.38 & $(0.03)$ & $* *$ \\
Erythrocytes, $\times 10^{12} \cdot \mathrm{I}^{-1}$ & 4.42 & $(0.38)$ & 4.08 & $(0.41)$ & $* * *$ \\
Leucocytes, $\times 10^{9} \cdot \mathrm{I}^{-1}$ & 6.4 & $(1.7)$ & 8.1 & $(2.4)$ & $* * *$ \\
Neutrophils, \% & 59.6 & $(7.3)$ & 63.9 & $(6.4)$ & $*$ \\
Neutrophils, $\times 10^{9} \cdot \mathrm{I}^{-1}$ & 3.84 & $(1.26)$ & 5.19 & $(1.70)$ & $* * *$ \\
Lymphocytes, \% & 28.5 & $(5.9)$ & 21.9 & $(6.9)$ & $* * *$ \\
Lymphocytes, $\times 10^{9} \cdot \mathrm{I}^{-1}$ & 1.77 & $(0.46)$ & 1.77 & $(0.67)$ & \\
Monocytes, \% & 7.4 & $(1.1)$ & 7.4 & $(1.8)$ & \\
Monocytes, $\times 10^{9} \cdot \mathrm{I}^{-1}$ & 0.48 & $(0.16)$ & 0.60 & $(0.23)$ & $*$ \\
Eosinophils, \% & 2.1 & $(1.2)$ & 3.4 & $(1.6)$ & $* * *$ \\
Eosinophils, $\times 10^{9} \cdot \mathrm{I}^{-1}$ & 0.14 & $(0.08)$ & 0.28 & $(0.14)$ & $* * *$ \\
Basophils, \% & 0.8 & $(0.4)$ & 1.1 & $(0.2)$ & $*$ \\
Basophils, $\times 10^{9} \cdot \mathrm{I}^{-1}$ & 0.06 & $(0.03)$ & 0.08 & $(0.03)$ & $* * *$ \\
\hline
\end{tabular}

Differences between pre- and postoperative values $\left({ }^{\star} P<0.05 ;{ }^{\star \star} P<0.01 ;{ }^{\star \star \star} P<0.001\right)$. 
seventh postoperative day. A postoperative decrease was also observed in haemoglobin concentration, haematocrit and erythrocyte count $(P<0.05-0.000)$.

The number of cells secreting spontaneously IgG, IgM and IgA against adenovirus, measles, rubella and tetanus (ASC) as well as the total numbers of cells spontaneously secreting IgG, IgM and IgA (ISC) had increased by the seventh postoperative day after coronary artery bypass surgery from preoperative values $(P<0.05-0.001)$ (Figure 1). By contrast, similar changes were not seen after PWM stimulation in ASC or ISC numbers. The tests showed decreased numbers of PWMstimulated IgG and IgM ASCs against adenovirus $(P<0.05)$ and increased numbers of IgA ASC against rubella on the seventh postoperative day $(P<0.05)$. No alterations were seen in the numbers of ASCs against measles or tetanus or in any of the ISC numbers.

Spontaneous lymphocyte proliferation, characterized by ${ }^{3} \mathrm{H}$-thymidine uptake, was increased on the seventh postoperative day $(P<0.05)$, but PHAinduced lymphocyte proliferative responses were depressed compared with preoperative values $(P<0.05)$. No differences were seen in PWM-induced responses between pre- and postoperative values (Table II).

No differences were seen between the patients and controls in any of the test values preoperatively, and no alterations were observed in any of the test values of the controls from the first to the second blood sample.

\section{Discussion}

This study measured antibody specificities of surgeryactivated cells, not the capacity of the body to respond to microbial or other antigens during or after operation. The focus was on the increased number of immunoglobulin secreting cells found in the circulation about one week after the operation, disregarding any immediate postoperative alterations in the immune response. The study confirmed the earlier finding of an increased number of cells spontaneously secreting IgG, IgM and IgA one week after open heart surgery. ${ }^{3}$ A novel finding was the several fold increase in the number of $\operatorname{IgG}, \operatorname{IgM}$ and IgA specific antibody secreting cells (ASC) against all antigens of different types (adenovirus, measles, rubella, and tetanus). This activation was more intensive than that induced by PWM. The activation affected all specific ASCs alike, supporting the hypothesis of nonspecific spontaneous polyclonal B cell activation after open-heart surgery. In accordance with our results, DiPadova et al. found production of antibodies against enterococcal and pneumococcal antigens in mononuclear cell cultures seven days after major surgery. ${ }^{12}$

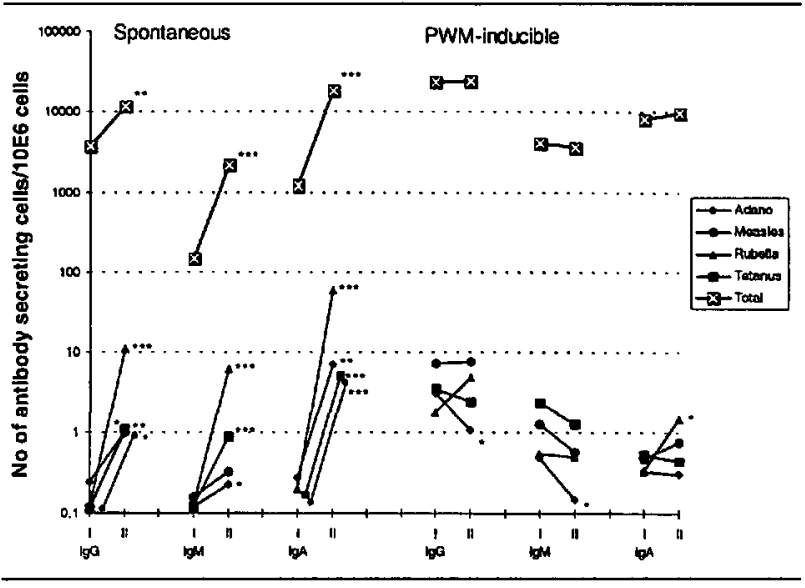

FIGURE 1 Numbers of cells showing spontaneous and PWMinduced secretion of IgG, IgM and IgA anti-adenovirus, - measles, -rubella, and -tetanus and total numbers of immunoglobulin secreting cells before operation (I) and on the seventh postoperative day (II). Geometric means, $\mathbf{n = 1 8}$.

Differences between pre- and postoperative values $\left({ }^{\star} P<0.05 ;{ }^{* *} P<0.01 ;{ }^{\star \star} P<0.001\right)$.

TABLE II Lymphocyte proliferative responses as disintegrations per minute (dpm) before operation (I) and on the seventh postoperative day (II). Median (25th and 75th percentile), $\mathrm{n}=18$.

\begin{tabular}{|c|c|c|c|}
\hline & & $I$ & $I I$ \\
\hline \multicolumn{4}{|c|}{$\begin{array}{l}\text { Lymphocyte proliferative } \\
\text { responses, dpm }\end{array}$} \\
\hline Unstimulated & 282 & $(199-341)$ & $(341-833)^{\star}$ \\
\hline PHA-induced & 159108 & $(98835-371197)$ & $110301(55032-215520)^{\star}$ \\
\hline PWM-induced & 122691 & $(56521-239043)$ & $117854(39193-190213)$ \\
\hline
\end{tabular}

Differences between pre- and postoperative values $\left({ }^{*} P<0.05\right)$.

Polyclonal B-cell activation has been seen during a vigorous immune response and during several viral and bacterial infections. ${ }^{13}$ Preferential synthesis of some viral antibodies, e.g., those specific for measles and rubella viruses, has been described. ${ }^{14}$ In this study the most prominent increase was seen in rubella virus antibodies. The response can be considered part of the nonspecific systemic inflammatory response associated with cardiac surgery and extracorporeal circulation ${ }^{15}$ and it includes activation of the complement, coagulation, fibrinolytic and kallikrein cascades, activation of neutrophils, free oxygen radical release and cytokine response. Among these factors, several cytokines, including $\mathrm{IL}-\mathrm{l}_{\alpha}, \mathrm{IL}-\mathrm{l}_{\beta}$ and $\mathrm{TNF}_{\alpha}$, stimulate B-cell responses and IgG, IgM and IgA secretion. ${ }^{16}$ Plasma cytokine concentrations were not measured, but proinflammatory (IL-I, IL-8 and TNF $\alpha$ ) and anti-inflammatory cytokines (IL-10) have been found to be 
increased by open-heart surgery. ${ }^{17}$ An association may occur between the spontaneous polyclonal B cell activation shown in this study and the cytokine response generated by surgical trauma, extracorporeal circulation and leakage of endotoxin into the blood circulation during cardiopulmonary bypass surgery..$^{18}$ Surgery alone, however, may be sufficient to produce the changes, as increased secretion of IgG and IgA has been seen seven days after cholecystectomy. ${ }^{12}$ After surgery, decreased production of $\mathrm{T}$ helper cell type 1 (TH1) cytokines IL-2 and IFN $\gamma^{19}$ and increased production of TH2 cytokines IL- ${ }^{20}$ and IL- $10^{17}$ has been described. This shift towards TH2 cells favours humoral immunity 21 and may be the underlying mechanism of B-cell activation. Some drugs, including high dose fentanyl, ${ }^{17}$ heparin ${ }^{22}$ and possibly $B$-adrenergic blocking drugs and calcium channel antagonists, ${ }^{23}$ used by these patients may also have an indirect effect by altering cytokine responses.

The finding in this study of lymphocytes with increased spontaneous proliferative activity characterized by increased ${ }^{3} \mathrm{H}$-thymidine uptake seven days after operation is in agreement with the other findings of this study. These DNA-synthesizing cells are possibly the same cells as the spontaneous ASCs and ISCs measured in this study. The increase in spontaneous proliferative activity can already be observed after coronary artery bypass surgery on the first postoperative day, and the response is over by the $10-14$ th postoperative day. ${ }^{2}$

The increased numbers of cells spontaneously secreting specific antibodies (ASCs) and immunoglobulin secreting cells (ISCs) can be expected to increase antiviral and antibacterial resistance and to maintain immunity against antigens to which the body has earlier been exposed. It can thus be proposed that surgery, as a stress situation, activates memory cells, and found in this study as polyclonal Bcell activation, to maintain the immune status in humans. Polyclonal B-cell activation may also be involved in the pathogenesis of autoimmune disease. ${ }^{24}$ On the other hand, the postoperative depression of cell-mediated immunity observed in this study as depressed PHA-induced lymphocyte proliferative responses is thought to protect the body from reacting against antigenic structures exposed during operation. ${ }^{2}$ It is thus possible that disturbed balance between polyclonal B-cell activation and depressed cell-mediated immunity after surgery may arouse autoimmune responses in patients prone to autoimmune disease. Although autoimmune disease occurs rarely, this should, however, be investigated in epidemiological studies.

\section{Acknowledgments}

The authors thank Professor Markku Inberg, Department of Cardiothoracic Surgery, Turku University Central Hospital for cooperation and Mrs Marjo Hakkarainen for skillful technical assistance.

\section{References}

1 Salo $M$. Effects of anaesthesia and surgery on the immune response. Acta Anaesthesiol Scand 1992; 36: 201-20.

2 Salo $M$. Effect of anaesthesia and open-heart surgery on lymphocyte responses to phytohaemagglutinin and concanavalin A. Acta Anaesthesiol Scand 1978; 22: 471-9.

3 Rybänen P, Ilonen J, Surcel $H-M$, et al. Characterization of in vivo activated lymphocytes found in the peripheral blood of parients undergoing cardiac operation. J Thorac Cardiovasc Surg 1987; 93: 109-14.

4 Salo $M$. Effect of anaesthesia and surgery on the number of and mitogen-induced transformation of $\mathrm{T}$ - and B-lymphocytes. Ann Clin Res 1978; 10: 1-13.

5 Böyum $A$. Isolation of mononuclear cells and granulocytes from human blood. Scand J Clin Lab Invest 1968; 21(Suppl 97): 77-89.

6 Czerkinsky CC, Nilsson L-Ä, Nygren H, Ouchterlony Ö, Tarkowski $A$. A solid-phase enzyme-linked immunospot (ELISPOT) assay for enumeration of specific antibodysecreting cells. J Immunol Methods 1983; 65: 109-21.

7 Mäkelä MJ, Nikkari S, Meurman O, Laine M, Arvilommi $H$. Virus-specific, antibody-secreting cells during upper respiratory infections. J Med Virol 1995; 47: 416-20.

8 Waris $M$, Halonen P. Purification of adenovirus hexon protein by high-performance liquid chromatography. J Chromatogr 1987; 397: 321-5.

9 Ilonen J. Lymphocyte blast transformation response of seropositive and seronegative subjects to herpes simplex, rubella, mumps and measles virus antigens. APMIS 1979; 87: 151-7.

10 Meurman $\mathrm{OH}$, Ziola BR. IgM-class rheumatoid factor interference in the solid-phase radioimmunoassay of rubella-specific IgM antibodies. J Clin Pathol 1978; 31: 483-7.

11 Eskola J, Soppi E, Viljanen M, Ruuskanen O. A new micromethod for lymphocyte stimulation using whole blood. Immunol Commun 1975; 4: 297-307.

12 Di Padova F, Durig M, Di Padova C, Pozzoli M, Tritapepe $R$. Spontaneous and polyclonal Ig secretion by circulating B cells after surgery. Surgery 1988; 103: 547-52.

13 Granholm NA, Cavallo $T$. Autoimmunity, polyclonal B-cell activation and infection. Lupus 1992; 1 : 63-74.

14 Salmi A, Reunanen M, Ilonen J, Panelius $M$. Intrathecal antibody synthesis to virus antigens in multiple sclerosis. Clin Exp Immunol 1983; 52: 241-9. 
15 Butler J, Rocker GM, Westaby S. Inflammatory response to cardiopulmonary bypass. Ann Thorac Surg 1993; 55: 552-9.

16 Tucci $A$, James $H$, Chicheportiche $R$, Bonnefoy $J-\Upsilon$, Dayer J-M, Zubler $R H$. Effects of eleven cytokines and of IL- 1 and tumor necrosis factor inhibitors in a human B cell assay. J Immunol 1992; 148: 2778-84.

17 McBride WT, Armstrong MA, Crockard AD, McMurray $T$, Rea JM. Cytokine balance and immunosuppressive changes at cardiac surgery: contrasting response between patients and isolated CPB circuits. $\mathrm{Br} \mathrm{J}$ Anaesth 1995; 75: 724-33.

18 Andersen LW, Landow L, Baek L, Jansen E, Baker S. Association between gastric intramucosal $\mathrm{pH}$ and splanchnic endotoxin, antibody to endotoxin, and tumor necrosis factor- $\alpha$ concentrations in patients undergoing cardiopulmonary bypass. Crit Care Med 1993; 21: 210-7.

19 Pirenne J, Ribbens $C$, Médot $M$, et al. Adverse effect of abdominal operations on production of interferon- $\gamma$. Eur J Surg 1995: 161: 77-83.

20 Decker $D$, Schöndorf $M$, Bidlingmaier $F$, Hirner $A$, von Ruecker $A A$. Surgical stress induces a shift in the type1/type-2 T-helper cell balance, suggesting down-regulation of cell-mediated and up-regulation of antibody-mediated immunity commensurate to the trauma. Surgery 1996; 119: 316-25.

21 Powrie $F$, Coffman $R L$. Cytokine regulation of T-cell function: potential for therapeutic intervention. Immunol Today 1993; 14: 270-4.

22 McBride WT, Armstrong MA, McMurray TJ. An investigation of the effects of heparin, low molecular weight heparin, protamine, and fentanyl on the balance of pro- and anti-inflammatory cytokines in in-vitro monocyte cultures. Anaesthesia 1996; 51: 634-40.

23 Sheeran P, Hall GM. Cytokine balance and immunosuppressive changes at cardiac surgery (Letter). $\mathrm{Br} \mathrm{J}$ Anaesth 1996; 77: 129.

24 Klinman $D M$, Steinberg $A D$. Systemic autoimmune disease arises from polyclonal B cell activation. J Exp Med 1987; 165: 1755-60. 